\title{
PRELIMINARY EVALUATION OF ACID MINE DRAINAGE IN MINAS GERAIS STATE, BRAZIL ${ }^{(1)}$
}

\author{
Jaime Wilson Vargas de Mello ${ }^{(2)}$, Luiz Eduardo Dias ${ }^{(2)}$, Alfredo \\ Mucci Daniel $^{(3)}$, Walter Antonio Pereira Abrahão ${ }^{(2)}$, Eleonora \\ Deschamps $^{(4)}$ \& Carlos Ernesto G.Reynald Schaefer ${ }^{(2)}$
}

\begin{abstract}
SUMMARY
Mining in the State of Minas Gerais-Brazil is one of the activities with the strongest impact on the environment, in spite of its economical importance. Amongst mining activities, acid drainage poses a serious environmental problem due to its widespread practice in gold-extracting areas. It originates from metalsulfide oxidation, which causes water acidification, increasing the risk of toxic element mobilization and water resource pollution. This research aimed to evaluate the acid drainage problem in Minas Gerais State. The study began with a bibliographic survey at FEAM (Environment Foundation of Minas Gerais State) to identify mining sites where sulfides occur. Substrate samples were collected from these sites to determine AP (acidity potential) and NP (neutralization potential). The AP was evaluated by the procedure of the total sulfide content and by oxygen peroxide oxidation, followed by acidity titration. The NP was evaluated by the calcium carbonate equivalent. Petrographic thin sections were also mounted and described with a special view to sulfides and carbonates. Based on the chemical analysis, the acid-base accounting (ABA) was determined by the difference of AP and NP, and the acid drainage potential obtained by the ABA value and the total volume of material at each site. Results allowed the identification of substrates with potential to generate acid drainage in Minas Gerais state. Altogether these activities represent a potential to produce between 3.1 to 10.4 billions of $\mathrm{m}^{3}$ of water at $\mathrm{pH} 2$ or 31.4 to 103.7 billions of $\mathrm{m}^{3}$ of water at $\mathrm{pH}$ 3. This, in turn, would imply in costs of US $\$ 7.8$ to 25.9 millions to neutralize the acidity with commercial limestone. These figures are probably underestimated because some mines were not surveyed, whereas, in other cases, surface samples may not represent reality. A more reliable state-wide evaluation of the acid drainage potential would require
\end{abstract}

\footnotetext{
(1) Pesquisa realizada com apoio financeiro da FAPEMIG. Recebido para publicação em janeiro de 2004 e aprovado em abril de 2006.

(2) Professor do Departamento de Solos, Universidade Federal de Viçosa - UFV. CEP 36571-000 Viçosa (MG). Bolsista do CNPq. E-mails: jwvmello@ufv.br; ledias@.ufv.br; carlos.schaefer@ufv.br

(3) Gerente de Pesquisa e Meio Ambiente. Rua procópio Ferreira 237, Cond. Horto Florestal, Bro. Horto, CEP 36770-000 Cataguases (MG). E-mail: geoambiente@gqc.com.br

(4) Fundação Estadual do Meio Ambiente - FEMA. Av. Prudente de Morais 1671, CEP 30380-000 Belo Horizonte (MG). E-mail: eleonorad@feam.br
} 
further studies, including a larger number of samples. Such investigations should consider other mining operations beyond the scope of this study as well as the kinetics of the acid generation by simulated weathering procedures.

Index terms: acid mine drainage, acid-base accounting; sulfide minerals.

\author{
RESUMO: AVALIAÇ̃̃O PRELIMINAR DE DRENAGEM ÁCIDA NO ESTADO \\ DE MINAS GERAIS, BRASIL
}

\begin{abstract}
A despeito da importância econômica de atividades mineralógicas para o estado de Minas Gerais, perceber-se que elas causam significativo impacto ao ambiente. Drenagem ácida é um dos aspectos ambientais considerados pela atividade em função de seus impactos. Ela tem origem a partir da oxidação de sulfetos metálicos que acidificam as águas, com possibilidade de mobilizar elementos tóxicos e poluir os recursos hídricos. Este trabalho teve como objetivo realizar uma avaliação preliminar do problema em Minas Gerais. O trabalho teve início a partir de um levantamento bibliográfico junto a Fundação Estadual de Meio Ambiente (FEAM) para identificar minerações cujo minério está associado a sulfetos. Amostras dos substratos foram retiradas para determinar o potencial de acidez (AP) e de neutralização (NP). AP foi avaliado por dois procedimentos: pelo teor total de sulfetos e pela oxidação com peróxido seguida da titulação ácida. O NP foi avaliado pelo teor equivalente de carbonato de cálcio. Lâminas petrográficas foram preparadas para a descrição mineralógica com ênfase em sulfetos e carbonatos. O balanço ácido-base ( $A B A)$ foi determinado pela diferença entre $A P$ e NP, enquanto o potencial de geração de águas ácidas foi obtido pelo valor de ABA e o volume total de material de cada atividade minerária. Os resultados permitiram identificar quatro substratos com potencial para gerar drenagem ácida no estado de Minas Gerais. Juntas, estes materiais representam um potencial de geração de cerca 3,14 a 10,37 bilhões de metros cúbicos de água a pH 2,0 ou 31,4 a 103,7 bilhões de metros cúbicos de água a pH 3,0. Estes valores significam custos entre US\$7,8 e 25,9 milhões para neutralizar a acidez com o uso de calcário. Estas estimativas são provavelmente subavaliadas, uma vez que algumas minerações não foram incluídas no levantamento e, para outras, as amostras superficiais podem não representar a realidade. Uma avaliação mais rígida do potencial de drenagem ácida em nível estadual requer estudos futuros. Estes estudos precisariam incluir um número maior de amostras e mineradoras não incluidas neste trabalho. Eles poderiam considerar, ainda, a cinética de geração de acidez por meio de procedimentos de intemperismo simulado.
\end{abstract}

Termos de indexação: drenagem ácida de minas; balanço ácido-base; minerais sulfetados.

\section{INTRODUCTION}

Mining is one the most important traditional and economical activities in Brazil, which accounts for considerable economic and social benefits. Nevertheless, mining is considered to cause a number of negative environmental impacts. Acid mine drainage (AMD) is one of the currently most discussed environmental problems. It is initiated during the mining process, where a variety of metallic sulfides is exposed to the atmosphere and spontaneously oxidizes in the presence of $\mathrm{O}_{2}$ (Geidel $\&$ Caruccio, 2000). Sulfide materials may also be exposed by highway construction and other large scale excavations (Skousen, 2000). The products of such reactions are not only highly soluble, but also strongly acidic. Thus, high sulphate and iron contents make the water drainage acid. If potentially toxic elements are present, such as $\mathrm{Al}, \mathrm{Mn}, \mathrm{Cu}, \mathrm{Zn}$, $\mathrm{Pb}, \mathrm{Hg}, \mathrm{Cd}$, etc., they are mobilized in the drainage water, increasing the risk of toxic metal incorporation in biological systems, promoting biomagnification by the trophic chain (Mello \& Abrahão, 1998). Among the sulfide minerals, pyrite and marcasite $\left(\mathrm{FeS}_{2}\right)$ are dominant in the state's mining regions, but other metals may be complexed with these sulfides, forming chalcopyrite $\left(\mathrm{CuFeS}_{2}\right)$, covellite $(\mathrm{CuS})$, galena $(\mathrm{PbS})$, sphalerite $(\mathrm{ZnS})$, and arsenopyrite (FeAsS).

In Brazil, AMD studies are recent, and the problem has been reported in coal mines in the states of Rio Grande do Sul and Santa Catarina (Soares, 1995). There are many mines in the state of Minas Gerais where sulfides are associated with manganese, gold, nickel, zinc, lead and uranium, with the potential to generate acid mine drainage (Santana Filho, 2000). 
The $\mathrm{pH}$ values of acid drainage (AD) in mined areas is usually below 3.5, with total amounts of soluble metals of over $50 \mathrm{mg} \mathrm{L}^{-1}$ (Ziemkiewics et al., 1977). In fact, high metal concentrations are common in acid drainage from coal mines, where average values of $\mathrm{Fe}$ and $\mathrm{Mn}$ in solution can vary from 20 to $300 \mathrm{mg} \mathrm{L}^{-1}$ and sulfate from 20 to $2,000 \mathrm{mg} \mathrm{L}^{-1}$ (Richards et al., 1993).

An important aspect to control the occurrence of $\mathrm{AD}$ is an accurate prediction of the acid-producing potential of the material. Several methods of determining the acidity potential (AP) have been proposed, for example: Smittenberg et al. (1951); Neckers \& Walker (1952); Murthy \& Sharada (1960); Pons (1964); Petersen (1969); Aspiras et al. (1972); Caruccio (1975); and Sorenson et al. (1979). In Brazil, Soares et al. (1997) used the "aqua regia" $\left(\mathrm{HNO}_{3}: \mathrm{HCl}\right.$ 1:3) digestion as a simplified method to evaluate the total sulfide content in coal mining samples from Rio Grande do Sul. Each of these methods measures either $\mathrm{S}$ or $\mathrm{Fe}$ associated with iron sulfides and therefore provides an indirect estimate of the potential acidity by the stoichiometric equation for pyrite oxidation. The constraints on such estimates are that sulfides other than pyrite may be present, which produce acidity in a different stoichiometry in relation to that of pyrite, as described by Singer and Stumm (1970). Such estimates would therefore require a detailed description and an accurate evaluation considering all sulfides present in the sample, which is a very laborious and demanding determination. To overcome this problem, the acidproducing potential can be measured directly. A rapid oxidation technique has been proposed with $30 \%$ $\mathrm{H}_{2} \mathrm{O}_{2}$ that oxidizes iron sulfides (Yoneda, 1961; Grube Jr. et al., 1971; Sobek et al., 1978), followed by a direct titration of the produced acid.

The occurrence of AMD is not only determined by the presence of sulfides since it is very common to find carbonates associated with sulfides, which may reduce or neutralize the acidity generated by sulfide oxidation. Acid-Base Accounting (ABA) is a widely used method to estimate the potential of acid generation (Sobek et al., 1978). It is calculated by the difference between the acidity (AP) and neutralization potential (NP). In the case of negative values, the neutralization potential of the substratum is higher than its potential of acidity and AMD is, therefore, not expected.

With regard to the fact that Brazilian environmental regulations are yet incipient concerning AMD aspects, the scope of the problem needs to be evaluated. It is therefore important to identify suitable simple analytical methods for such an assessment. The "aqua regia" digestion appears to be a simple enough option for AMD studies.

The present study aimed to compare direct measures of the acid-producing potential technique as described by O'Shay et al. (1990) with the total sulfide oxidation evaluated by the "aqua regia" digestion technique. Furthermore, the potential of some mining activities in the state of Minas Gerais, Brazil to generate acid drainage was outlined in a preliminary evaluation.

\section{MATERIAL AND METHODS}

In a thorough bibliographic survey at the Minas Gerais Environmental Agency (FEAM), sites where mining activities are associated with sulfides were identified. Seven large mining sites were listed whose activities have the potential to generate acid drainage, including uranium, nickel, gold, and zinc exploitations. The second step consisted in the sampling of the different substrates including ore, overburden, and tail (Table 1 ) according to the peculiarities of each mine. In all situations, at least three simple surface (0-0.2 m) samples were taken to compose the final sample.

After each sample had been dried and ground $(0.149 \mathrm{~mm})$, analyses were carried out to determine the $\mathrm{pH}$ and electrolytic conductivity (EC) in water $(1: 2.5 \mathrm{v} / \mathrm{v})$, the acidity potential (AP) and neutralization potential (NP). AP was evaluated by two procedures: total sulfide content after $\mathrm{HCl}+\mathrm{HNO}_{3}$ mixture (3:1 v/v) digestion (Soares, $1995)$ and oxygen peroxide (30 \%) oxidation followed by acidity titration (O'Shay et al., 1990). NP was evaluated as calcium carbonate equivalent by titration of the remaining $\mathrm{HCl}$ after reaction with a ground sample (Embrapa, 1979). Based on the chemical analysis, the acid-base accounting (ABA) was determined by the difference of AP and NP. The generation potential of acid drainage was obtained from ABA values and the total amounts of the respective materials of each mining activity. This potential was stated as acid water volume at $\mathrm{pH} 2.0$ or 3.0 .

Petrographic thin sections were produced after impregnating representative rock samples from each site. The main minerals were described, focusing on the presence of sulfite/carbonate. Sulfites were identified based on the following criteria (Winchell, 1933; Kerr, 1977):

- Pyrite $\left(\mathrm{FeS}_{2}\right)$ was identified by cubic to octahedral crystals, opaque, showing a brilliant metallic luster, creamy white color under reflected light and yellowish colors under dimmed reflected light.

- Sphalerite $(\mathrm{ZnS})$ was identified by isotropic tetrahedral crystals, with refringence, brownish to yellow color, with spectral tonality.

- Pyrrhotite (FeS) was identified by hexagonal prism, opaque crystals, produced marked rotation of the polarization plane under 
Table 1. Description of different materials sampled at each mining site

\begin{tabular}{|c|c|c|c|}
\hline Site & Ore & Sampled material & Point of sampling \\
\hline A & Uranium & Overburden & $\begin{array}{l}\text { Surface samples at the bottom, center and top of } \\
\text { the piles. }\end{array}$ \\
\hline B & Nickel & $\begin{array}{l}\text { High content, intermediate } \\
\text { and low content ores, } \\
\text { overburden and tailing. }\end{array}$ & $\begin{array}{l}\text { Ore and overburden sampled from piles and tailing } \\
\text { from tailing ponds. }\end{array}$ \\
\hline $\mathrm{C}$ & Gold & $\begin{array}{l}\text { Two kinds of non-oxidized ore } \\
\text { B1 and B2 }\end{array}$ & Ore sampled directly from the mining area. \\
\hline $\mathrm{D}$ & Gold & Ore, tailing and overburden & $\begin{array}{l}\text { Ore sampled from piles and tailing from tailing } \\
\text { ponds }\end{array}$ \\
\hline $\mathrm{E}$ & Gold & Ore, overburden and tailing & $\begin{array}{l}\text { Ore and overburden sampled from the piles and } \\
\text { tailing from tailing ponds. }\end{array}$ \\
\hline $\mathrm{F}$ & Zinc & Ore and tailing & Ore and tailing sampled from piles. \\
\hline $\mathrm{G}$ & Zinc and lead & Ore, overburden and tailing & $\begin{array}{l}\text { Overburden from piles, ore from the strap loader } \\
\text { and tailing from tailing ponds }\end{array}$ \\
\hline
\end{tabular}

reflected light; Color yellow to copper, darker than pyrite; cream-colored under vertical reflected light; usually associated with chalcopyrite.

- Arsenopyrite (FeAsS) with octahedral to subhedral prismatic crystals, silvery white to grayish, white color under vertical reflected light, commonly intergrown with chalcopyrite and especially pyrite.

- Chalcopyrite (CuFeS) was identified by tetrahedral crystals, often striated, of brassyellow color, light yellow under vertical reflected light; there was no visible plane rotation under polarized reflected light.

In the overall discussion the mining companies were identified by letters rather than by names, hence preserving their legal rights and to avoid ethical issues.

\section{RESULTS AND DISCUSSION}

\section{$\mathrm{pH}$, electrolytic conductivity, sulfur and carbonate contents}

According to the $\mathrm{pH}$ values, the samples were classified in two groups. The first one had low to very low $\mathrm{pH}$ values (2.6 to 5.4) and included samples from sites A, B, and C (Table 2), with exception of site $\mathrm{B}$ overburdens which presented lower sulfide content and the presence of carbonates. The group formation was corroborated by the microscopic observation of thin sections under high magnification (Figure 1). The low pH suggests the presence of sulfides and, possibly, AMD. The second group, including samples from sites D, E, F, and G, showed high $\mathrm{pH}$ values (> 7.0) due to the substantial presence of carbonates. Among all sites, the highest (9.5) as well as lowest (5.5) pH values were observed in tails from a gold mining site.

The high $\mathrm{pH}$ values associated with the presence of carbonates are in agreement with the geology of each area. Samples from sites F and G showed high $\mathrm{pH}$ values due to the dominance of carbonates in the limestone and dolomites of the Bambuí Group. Samples from sites D and E showed high $\mathrm{pH}$ values ascribed to the presence of carbonates associated to the Banded Iron Formation (BIF) of the Rio das Velhas Supergroup. In such cases, not only calcium (calcite) and magnesium (dolomite), but also iron (siderite) are expected. It is worth mentioning that the presence of siderite in a sample can overrate its neutralization potential (Caruccio and Geidel, 1996). Higher $\mathrm{pH}$ values than expected in a saturated $\mathrm{CaCO}_{3}$ solution in equilibrium with atmospheric $\mathrm{CO}_{2}$ are probably associated with the presence of salts or hydroxides, arising from the mineral concentration process.

The EC results showed greater variability than $\mathrm{pH}$. Values ranged from $0.04 \mathrm{dS} \mathrm{m}^{-1}$ in ore B1 from site C to $17.56 \mathrm{dS} \mathrm{m}^{-1}$ in tailing from site D. The highest EC values are expected in tailing samples due to the mineral concentration process. In general, EC values are higher in samples containing sulfides and are associated with the AMD process. Sulfide oxidation involves solubilization reactions that increase the ionic activity and, consequently, raise EC values.

\section{Acid base accounting}

The different ABA values resulting after subtracting the acidity (AP) from the neutralization potential (NP) (Table 3) only allowed an identification of the AMD potentiality in overburden samples from 
Table 2. pH and electrolytical conductivity values and total sulfur and carbonate content of the materials sampled at each mining company

\begin{tabular}{|c|c|c|c|c|c|}
\hline Company & Sample & $\mathbf{p H}$ & $\mathbf{C E}$ & $\mathbf{S}$ & $\mathrm{CaCO}_{3}$ \\
\hline \multirow{12}{*}{$\mathrm{A}$} & & & $\mathrm{d} \mathrm{S} \mathrm{m}^{-1}$ & 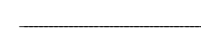 & \\
\hline & Overburden 1a & 4.43 & 1.46 & $23.4 \pm 0.076$ & 0 \\
\hline & Overburden $1 \mathrm{~b}$ & 3.93 & 1.51 & $14.1 \pm 0.003$ & $3.9 \pm 0.285$ \\
\hline & Overburden $1 \mathrm{c}$ & 2.69 & 2.78 & $8.5 \pm 0.022$ & $4.8 \pm 0.139$ \\
\hline & Overburden $1 \mathrm{~d}$ & 3.76 & 1.75 & $9.6 \pm 0.057$ & $9.9 \pm 0.277$ \\
\hline & Overburden 2 & 3.87 & 2.10 & $19.4 \pm 0.035$ & $2.6 \pm 0.655$ \\
\hline & Overburden $3 \mathrm{a}$ & 3.35 & 1.78 & $14.9 \pm 0.055$ & $0.4 \pm 0,674$ \\
\hline & Overburden $3 \mathrm{~b}$ & 4.03 & 1.24 & $8.9 \pm 0.025$ & $8.3 \pm 0.612$ \\
\hline & Overburden $3 \mathrm{c}$ & 4.37 & 2.06 & $7.7 \pm 0.031$ & $1.4 \pm 0.279$ \\
\hline & Overburden $3 \mathrm{~d}$ & 4.06 & 1.75 & $7.6 \pm 0.022$ & 0 \\
\hline & Overburden $3 \mathrm{e}$ & 3.82 & 1.66 & $9.8 \pm 0.006$ & $1.5 \pm 0.618$ \\
\hline & Overburden 4 & 2.63 & 4.22 & $41.7 \pm 0.209$ & 0 \\
\hline \multirow[t]{6}{*}{ B } & Ore 1 (High) & 3.45 & 7.56 & $189.0 \pm 1.327$ & $6.4 \pm 0.550$ \\
\hline & Ore 2 (Medium) & 4.26 & 4.21 & $113.6 \pm 0.869$ & $14.5 \pm 0.004$ \\
\hline & Ore 3 (Low) & 4.57 & 3.04 & $23.4 \pm 0.080$ & $33.2 \pm 0.837$ \\
\hline & Overburden 1 & 6.45 & 1.25 & $0.8 \pm 0.006$ & $55.3 \pm 0.277$ \\
\hline & Overburden 2 & 8.22 & 0.30 & $10.7 \pm 0.022$ & $44.1 \pm 2.798$ \\
\hline & Tail & 3.05 & 9.28 & $26.1 \pm 0.059$ & $45.0 \pm 0.293$ \\
\hline \multirow[t]{6}{*}{$\mathrm{C}$} & Ore B2a & 4.07 & 1.11 & $6.7 \pm 0.024$ & $3.8 \pm 0.650$ \\
\hline & Ore B2b & 4.19 & 0.45 & $9.6 \pm 0.020$ & $23.1 \pm 0.288$ \\
\hline & Ore B2c & 4.59 & 0.30 & $3.2 \pm 0.028$ & 0 \\
\hline & Ore B2d & 4.21 & 1.66 & $8.7 \pm 0.067$ & $19.8 \pm 0.276$ \\
\hline & Ore B1a & 5.38 & 0.04 & $1.1 \pm 0.008$ & $3.9 \pm 0.138$ \\
\hline & Ore B1b & 4.85 & 0.07 & $1.0 \pm 0.010$ & $4.4 \pm 0.609$ \\
\hline \multirow[t]{12}{*}{$\mathrm{D}$} & Overburden 1 & 7.94 & 0.11 & $1.1 \pm 0.011$ & $55.8 \pm 0.262$ \\
\hline & Ore 1 & 7.98 & 1.39 & $47.7 \pm 0.464$ & $173.7 \pm 2.901$ \\
\hline & Ore 2 & 8.33 & 0.28 & $49.0 \pm 0.063$ & $180.5 \pm 9.657$ \\
\hline & Tail 1 & 8.04 & 2.00 & $3.3 \pm 0.016$ & $220.4 \pm 13.026$ \\
\hline & Ore 3 & 6.73 & 0.12 & $1.3 \pm 0.004$ & $51.8 \pm 0.549$ \\
\hline & Overburden 2 & 8.11 & 0.13 & $0.8 \pm 0.004$ & $55.2 \pm 0.287$ \\
\hline & Overburden 3 & 6.63 & 0.03 & $2.6 \pm 0.004$ & $43.1 \pm 0.569$ \\
\hline & Overburden 4 & 8.48 & 0.22 & $2.2 \pm 0.011$ & $243.6 \pm 1.218$ \\
\hline & Tail 2 & 7.87 & 0.93 & $11.9 \pm 0.046$ & $201.0 \pm 0.583$ \\
\hline & Tail 3 & 8.05 & 0.87 & $3.8 \pm 0.024$ & $232.7 \pm 0.558$ \\
\hline & Tail 4 & 9.51 & 2.33 & $9.1 \pm 0.021$ & $39.7 \pm 0.278$ \\
\hline & Tail 5 & 5.51 & 17.56 & $116.5 \pm 0.079$ & $256.8 \pm 0.539$ \\
\hline \multirow[t]{3}{*}{$\mathrm{E}$} & Overburden & 8.49 & 0.39 & $6.4 \pm 0.063$ & $75.0 \pm 0.285$ \\
\hline & Ore & 8.00 & 0.56 & $33.5 \pm 0.161$ & $142.7 \pm 0.970$ \\
\hline & Tail & 8.02 & 2.31 & $21.7 \pm 0.069$ & $113.0 \pm 0.305$ \\
\hline \multirow[t]{2}{*}{$\mathrm{F}$} & Ore & 8.88 & 0.16 & $1.9 \pm 0.010$ & $203.2 \pm 1.240$ \\
\hline & Tail & 8.65 & 0.07 & $2.4 \pm 0.015$ & $763.2 \pm 14.272$ \\
\hline \multirow[t]{3}{*}{$\mathrm{G}$} & Ore & 8.89 & 0.31 & $34.6 \pm 0.217$ & $916.4 \pm 1.100$ \\
\hline & Tail & 7.70 & 2.04 & $18.1 \pm 0.172$ & $978.2 \pm 2.543$ \\
\hline & Overburden & 9.24 & 0.24 & $18.2 \pm 0.058$ & $991.0 \pm 2.676$ \\
\hline
\end{tabular}

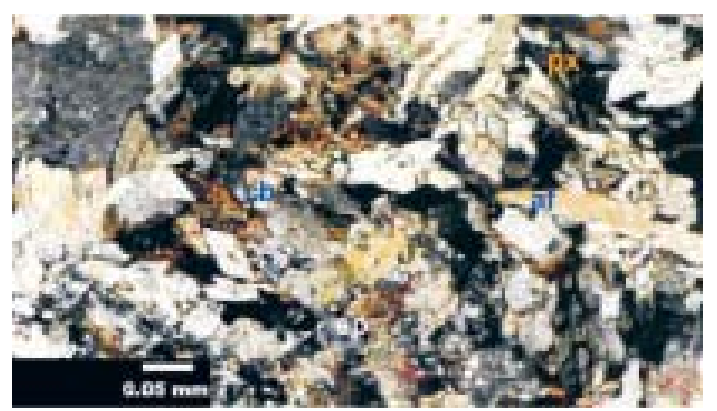

Figure 1. Photomicrograph under transmitted light with crossed polarizers showing crystals of pyroxene (px), amphibole (af), epidote (ep) and carbonate (cb). site A, ore samples from site $\mathrm{C}$, ore and tail samples from site B, and in an old tail (5) from site D. The ABA estimates resulted in different values of acid drainage potential according to the adopted criteria. Table 3 shows that the total sulfide content criteria resulted in higher ABA values, probably due to the presence of other sulfides such as chalcopyrite (samples from sites B and C), sphalerite (site A) and pentlandite (site B), as well as arsenopyrite (sites A, $\mathrm{C}$, and $\mathrm{E}$ ) besides pyrrhotites. The presence of such a variety of sulfide minerals, identified by petrographic observation (Figures 2 to 6 ), may have resulted in overestimated $\mathrm{ABA}$ values since the acid generation reactions from these sulfides probably have an stoichiometry other than pyrite. In this 
Table 3. Acidity potential (AP) obtained by total $\mathrm{S}$ and $\mathrm{H}_{2} \mathrm{O}_{2}$ procedures, neutralization potential (NP) and acid-base accounting (ABA) values for different materials sampled at each mining company

\begin{tabular}{|c|c|c|c|c|c|c|}
\hline \multirow{2}{*}{ Company } & \multirow{2}{*}{ Sample } & \multicolumn{2}{|c|}{$\mathbf{A P}$} & \multirow{2}{*}{$\mathbf{N P}$} & \multicolumn{2}{|c|}{ ABA } \\
\hline & & Total S & $\mathrm{H}_{2} \mathrm{O}_{2}$ & & Total S & $\mathrm{H}_{2} \mathrm{O}_{2}$ \\
\hline \multirow{12}{*}{$\mathrm{A}$} & & & 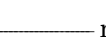 & & & - \\
\hline & Overburden $1^{\mathrm{a}}$ & 1463 & 923 & 0 & 1463 & 923 \\
\hline & Overburden $1 \mathrm{~b}$ & 881 & 478 & 77 & 804 & 401 \\
\hline & Overburden $1 \mathrm{c}$ & 531 & 103 & 97 & 434 & 6 \\
\hline & Overburden $1 \mathrm{~d}$ & 600 & 256 & 199 & 401 & 57 \\
\hline & Overburden 2 & 1213 & 291 & 51 & 1162 & 240 \\
\hline & Overburden $3 \mathrm{a}$ & 931 & 1316 & 9 & 922 & 1307 \\
\hline & Overburden $3 \mathrm{~b}$ & 556 & 222 & 167 & 389 & 55 \\
\hline & Overburden $3 \mathrm{c}$ & 481 & 120 & 28 & 453 & 92 \\
\hline & Overburden $3 \mathrm{~d}$ & 475 & 85 & 0 & 475 & 85 \\
\hline & Overburden $3 \mathrm{e}$ & 613 & 256 & 30 & 583 & 226 \\
\hline & Overburden 4 & 2606 & 683 & 0 & 2606 & 683 \\
\hline \multirow[t]{6}{*}{$\mathrm{B}$} & Ore (high) & 11813 & 8202 & 128 & 11685 & 8074 \\
\hline & Ore (Intermediate) & 7100 & 5020 & 289 & 6811 & 4731 \\
\hline & Ore (low) & 1463 & 513 & 665 & 798 & -152 \\
\hline & Overburden 1 & 50 & 0 & 1106 & -1056 & -1106 \\
\hline & Overburden 2 & 669 & 555 & 881 & -212 & -326 \\
\hline & Tail & 1631 & 1487 & 900 & 731 & 587 \\
\hline \multirow[t]{6}{*}{$\mathrm{C}$} & Ore B2a & 419 & 256 & 75 & 344 & 181 \\
\hline & Ore B2b & 600 & 410 & 462 & 138 & -52 \\
\hline & Ore B2c & 197 & 129 & 0 & 197 & 128 \\
\hline & Ore B2d & 544 & 307 & 397 & 147 & -90 \\
\hline & Ore B1a & 69 & 0 & 79 & -10 & -79 \\
\hline & Ore B1b & 63 & 0 & 88 & -25 & -88 \\
\hline \multirow[t]{12}{*}{$\mathrm{D}$} & Overburden 1 & 69 & 325 & 1116 & -1047 & -791 \\
\hline & Ore 1 & 2981 & 814 & 3475 & -494 & -2661 \\
\hline & Ore 2 & 3063 & 673 & 3610 & -547 & -2937 \\
\hline & Tail 1 & 206 & 359 & 4408 & -4202 & -4049 \\
\hline & Ore 3 & 81 & 34 & 1036 & -955 & -1002 \\
\hline & Overburden 2 & 50 & 17 & 1103 & -1053 & -1086 \\
\hline & Overburden 3 & 163 & 51 & 862 & -699 & -811 \\
\hline & Overburden 4 & 138 & 0 & 4872 & -4734 & -4872 \\
\hline & Tail 2 & 744 & 0 & 4019 & -3275 & -4019 \\
\hline & Tail 3 & 238 & 547 & 4655 & -4417 & -4108 \\
\hline & Tail 4 & 569 & 68 & 794 & -225 & -726 \\
\hline & Tail 5 & 7281 & 7156 & 5136 & 2145 & 2020 \\
\hline \multirow[t]{3}{*}{$\mathrm{E}$} & Overburden & 400 & 0 & 1499 & - 1099 & -1499 \\
\hline & Ore & 2094 & 854 & 2855 & -761 & -2001 \\
\hline & Tail & 1356 & 239 & 2261 & -905 & -2022 \\
\hline \multirow[t]{2}{*}{$\mathrm{F}$} & Ore & 119 & 0 & 4064 & -3945 & -4064 \\
\hline & Tail & 150 & 137 & 15264 & -15114 & -15127 \\
\hline \multirow[t]{3}{*}{$\mathrm{G}$} & Ore & 2163 & 0 & 18328 & -16165 & -18328 \\
\hline & Tail & 1131 & 0 & 19564 & -18433 & -19564 \\
\hline & Overburden & 1138 & 0 & 19820 & -18682 & -19820 \\
\hline
\end{tabular}

case, AP estimates of the total S content, after "aqua regia" digestion, were calculated on the basis of pyrite oxidation stoichiometry, as described by Singer \& Stumm (1970). On the other hand, estimates from $\mathrm{H}_{2} \mathrm{O}_{2}$ oxidation by the method of O'Shay et al. (1990) are probably underestimated, due to incomplete sulfide oxidation, as verified by Corrêa et al. (2002). An evaluation of the true potential of generating acid water, the costs and environmental risks must consider the peculiarities of each situation. The actual values probably range somewhere between the estimates of both criteria.

\section{AMD estimates}

The ABA values, in mols per metric ton (Table 3) were converted to liters per metric ton of acid water at $\mathrm{pH} 2.0$ or 3.0. The total acid water volumes were calculated from the ABA values versus the mass (in metric tons) of each material (Tables 4 and 5). The calculations were only carried out for samples with an acid drainage potential (i.e., with positive ABA values), taking the mean values of the same materials. Thus, the estimates of acid drainage reached $13.3 \times 10^{9} \mathrm{~m}^{3}$ of acid water at $\mathrm{pH} 2.0$, or 


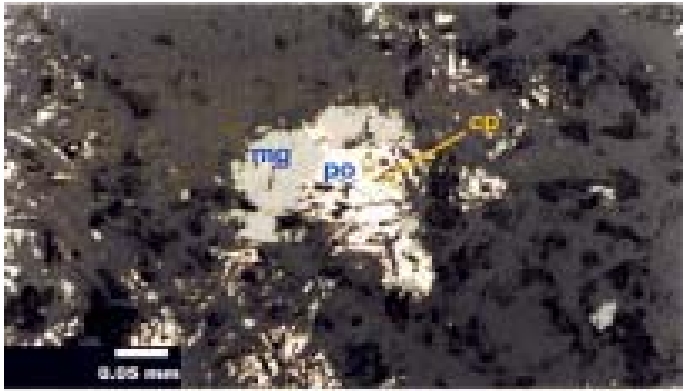

Figure 2. Photomicrograph under reflected light with parallel polarizers showing intergrowing of chalcopyrite (cp) droplets in pyrrhotite (po) as anhedral crystals, and magnetite (mg) as anhedral mass.

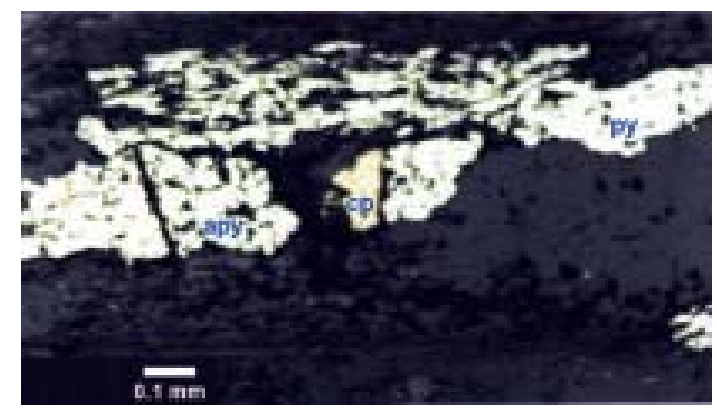

Figure 3. Photomicrograph under reflected light with parallel polarizers. In the picture intergrowing of chalcopyrite (cp), pyrite (py) and arsenopyrite (apy).

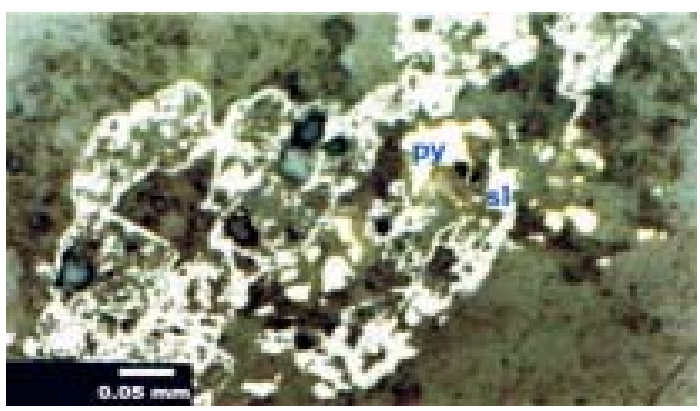

Figure 4. Photomicrograph under reflected light with parallel polarizers showing anhedral crystals of pyrite (py) and ground mass of sphalerite (sl) at the center.

$132.8 \times 10^{9} \mathrm{~m}^{3}$ at $\mathrm{pH} 3.0$ according to the calculations, and considering the total S content extracted by "aqua regia" (Table 4). On the other hand, the hydrogen peroxide criteria presented estimates of around $5.9 \times 10^{9} \mathrm{~m}^{3}$ with $\mathrm{pH} 2.0$ or $58.9 \times 10^{9} \mathrm{~m}^{3}$ with $\mathrm{pH} 3.0$ (Table 5). The real contribution to the acid drainage generation depends on the different mitigation measures adopted by local companies, as mentioned below.

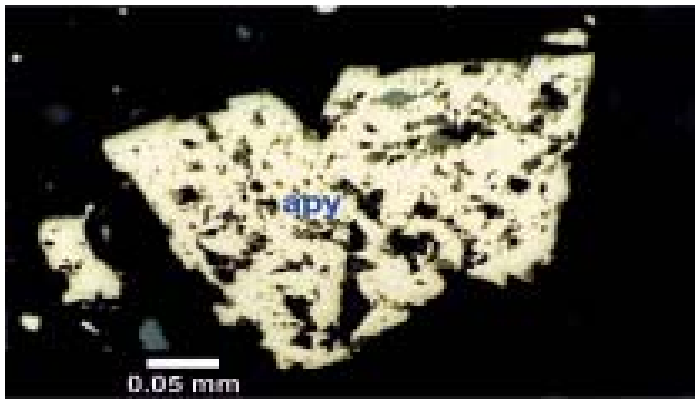

Figura 5. Photomicrograph under transmitted light with parallel polarizers. In the picture subhedral to euhedral arsenopyrite (apy) crystals.

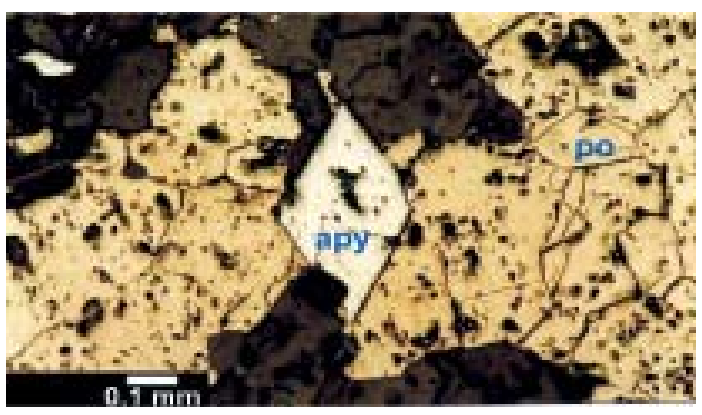

Figure 6. Photomicrograph under reflected light with parallel polarizers. In the picture euhedral arsenopyrite (apy) crystal wrapped in anhedral mass of pyrrhotite (po).

In the case of site A, mining activities have ceased and acid water arises from the sampled overburdens. Thus, the estimate of acid drainage for site A is between 2.42 and $5.28 \times 10^{9} \mathrm{~m}^{3}$ of acid water at pH 2.0 or 24.2 to $52.8 \times 10^{9} \mathrm{~m}^{3}$ at pH 3.0 (Tables 4 and 5). It is known that the company mitigates the problem by damming and neutralizing the acid water. Besides, the overburden piles were covered with clayey soil to seal them.

Site B has a potential for acid drainage generation of around $2.24 \times 10^{9} \mathrm{~m}^{3}$ of acid water at $\mathrm{pH} 2.0$ or $22.4 \times 10^{9} \mathrm{~m}^{3}$ at $\mathrm{pH} 3.0$, according to the lowest estimate criterion (Table 5). Nevertheless, ore processing at this mine includes a plant for sulphuric acid production, which decreases acid generation by $68.1 \%$, from $421,767 \mathrm{~L} \mathrm{t}^{-1}$ in the ore to $58,700 \mathrm{~L} \mathrm{t}^{-1}$ in tailing, according to the lowest estimate at $\mathrm{pH} 2.0$. Calculations of the acid water generation should therefore take into consideration that $46 \%$ of the ore is converted into tailing (Brandt, 1996). Thus, $5,207,066 \mathrm{t}$ of ore produce around 2,395,250 t of tailing and the acid generation potential would be between 185 and 230 millions $\mathrm{m}^{3}$ of water at $\mathrm{pH} 2.0$ or 1.85 to $2.30 \times 10^{9} \mathrm{~m}^{3}$ at $\mathrm{pH} 3.0$ (Table 6). Another consideration is that approximately a third part of 
Table 4. Acid water generation potential with pH 2.0 and pH 3.0, as estimated by the total sulfide content criteria for different materials sampled at each mining company

\begin{tabular}{|c|c|c|c|c|c|c|}
\hline \multirow{2}{*}{ Company } & \multirow{2}{*}{ Sample } & \multicolumn{2}{|c|}{ Acid water volume ( $\left.\mathrm{L} \mathrm{t}^{-1}\right)$} & \multirow{2}{*}{ Mass of materials (t) } & \multicolumn{2}{|c|}{ Acid water volume $(1.000 \mathrm{~L})$} \\
\hline & & pH 2 & pH 3 & & pH 2 & pH3 \\
\hline \multirow[t]{14}{*}{$\mathrm{A}$} & Overburden 1a & 146,300 & $1,463,000$ & & & \\
\hline & Overburden $1 \mathrm{~b}$ & 80,400 & 804,000 & & & \\
\hline & Overburden $1 \mathrm{c}$ & 43,400 & 434,000 & & & \\
\hline & Overburden $1 \mathrm{~d}$ & 40,100 & 401,000 & & & \\
\hline & Mean Overburden 1 & 77,550 & 775,500 & $34,650,000$ & $2.69 \times 10^{9}$ & $2.69 \times 10^{10}$ \\
\hline & Overburden 2 & 116,200 & $1,162,000$ & $5,520,000$ & $6.41 \times 10^{8}$ & $6.41 \times 10^{9}$ \\
\hline & Overburden $3 \mathrm{a}$ & 92,200 & 922,000 & & & \\
\hline & Overburden $3 \mathrm{~b}$ & 38,900 & 389,000 & & & \\
\hline & Overburden $3 \mathrm{c}$ & 45,300 & 453,000 & & & \\
\hline & Overburden $3 \mathrm{~d}$ & 47,500 & 475,000 & & & \\
\hline & Overburden $3 \mathrm{e}$ & 58,300 & 583,000 & & & \\
\hline & Mean Overburden 3 & 56,440 & 564,400 & $28,520,000$ & $1.61 \times 10^{9}$ & $1.61 \times 10^{10}$ \\
\hline & Overburden 4 & 260,600 & $2,606,000$ & $1,293,600$ & $3.37 \times 10^{8}$ & $3.37 \times 10^{9}$ \\
\hline & Total & & & & $5.28 \times 10^{9}$ & $5.28 \times 10^{10}$ \\
\hline \multirow[t]{7}{*}{$\mathrm{B}$} & Ore (high) & $1,168,500$ & $11,685,000$ & & & \\
\hline & Ore (Intermediate) & 681,100 & $6,811,000$ & & & \\
\hline & Ore (low) & 79,800 & 798,000 & & & \\
\hline & Mean of the ores & 643,133 & $6,431,330$ & $5,207,066$ & $3.35 \times 10^{9}$ & $3.35 \times 10^{10}$ \\
\hline & Tail & 73,100 & 731,000 & 750,000 & $5.48 \times 10^{7}$ & $5.48 \times 10^{8}$ \\
\hline & Ore B2a & 34,400 & 344,000 & & & \\
\hline & Ore B2b & 13,800 & 138,000 & & & \\
\hline \multirow[t]{3}{*}{$\mathrm{C}$} & Ore B2c & 19,700 & 197,000 & & & \\
\hline & Ore B2d & 14,700 & 147,000 & & & \\
\hline & Mean Ore B2 & 20,650 & 206,500 & $203,231,491$ & $4.20 \times 10^{9}$ & $4.20 \times 10^{10}$ \\
\hline $\mathrm{D}$ & Tail 5 & 214,500 & $2,145,000$ & $1,859,850$ & $3.99 \times 10^{8}$ & $3.99 \times 10^{9}$ \\
\hline Total & & & & & $13.28 \times 10^{9}$ & $13.28 \times 10^{10}$ \\
\hline
\end{tabular}

Table 5. Acid water generation potential with $\mathrm{pH} 2.0$ and $\mathrm{pH} 3.0$, as estimated by the $\mathrm{H}_{2} \mathrm{O}_{2}$ digestion criteria for different materials sampled at each mining company

\begin{tabular}{|c|c|c|c|c|c|c|}
\hline \multirow{2}{*}{ Company } & \multirow{2}{*}{ Sample } & \multicolumn{2}{|c|}{ Acid water volume $\left(\mathrm{L} \mathrm{t}^{-1}\right)$} & \multirow{2}{*}{ Mass of material (t) } & \multicolumn{2}{|c|}{ Acid water volume $(1.000 \mathrm{~L})$} \\
\hline & & pH 2 & pH 3 & & pH 2 & pH3 \\
\hline \multirow[t]{6}{*}{ A } & $\begin{array}{l}\text { Overburden } 1 \mathrm{a} \\
\text { Overburden } 1 \mathrm{~b} \\
\text { Overburden } 1 \mathrm{c} \\
\text { Overburden } 1 \mathrm{~d}\end{array}$ & $\begin{array}{c}92,300 \\
40,100 \\
600 \\
5,700\end{array}$ & $\begin{array}{r}923,000 \\
401,000 \\
6,000 \\
57,000\end{array}$ & & & \\
\hline & Mean Overburden 1 & 34,675 & 346,750 & $34,650,000$ & $1.20 \times 10^{9}$ & $1.20 \times 10^{10}$ \\
\hline & Overburden 2 & 24,000 & 240,000 & $5,250,000$ & $1.26 \times 10^{8}$ & $1.26 \times 10^{9}$ \\
\hline & $\begin{array}{l}\text { Overburden } 3 \mathrm{a} \\
\text { Overburden } 3 \mathrm{~b} \\
\text { Overburden } 3 \mathrm{c} \\
\text { Overburden } 3 \mathrm{~d} \\
\text { Overburden } 3 \mathrm{e} \\
\text { Mean Overburden } 3\end{array}$ & $\begin{array}{r}130,700 \\
5,500 \\
9,200 \\
8,500 \\
22,600 \\
35,300\end{array}$ & $\begin{array}{l}1,307,000 \\
55,000 \\
92,000 \\
85,000 \\
226,000 \\
353,000\end{array}$ & $28,520,000$ & $1.01 \times 10^{9}$ & $1.01 \times 10^{10}$ \\
\hline & Overburden 4 & 68,300 & 683,000 & $1,293,000$ & $8.83 \times 10^{7}$ & $8.83 \times 10^{8}$ \\
\hline & Total & & & & $2.42 \times 10^{9}$ & $2.42 \times 10^{10}$ \\
\hline \multirow[t]{2}{*}{$\mathrm{B}$} & $\begin{array}{l}\text { Ore (high) } \\
\text { Ore (Intermediate) } \\
\text { Ore (low) } \\
\text { Mean of all ores }\end{array}$ & $\begin{array}{r}807,400 \\
473,100 \\
-15,200 \\
421,767\end{array}$ & $\begin{array}{r}8,074,000 \\
4,731,000 \\
-152,000 \\
4,217,670\end{array}$ & $5,207,066$ & $2.20 \times 10^{9}$ & $2.20 \times 10^{10}$ \\
\hline & Tail & 58,700 & 587,000 & 750,000 & $4.40 \times 10^{7}$ & $4.40 \times 10^{8}$ \\
\hline $\mathrm{C}$ & $\begin{array}{l}\text { Ore B2a } \\
\text { Ore B2b } \\
\text { Ore B2c } \\
\text { Ore B2d } \\
\text { Mean Ore B2 }\end{array}$ & $\begin{array}{r}18,100 \\
-5,200 \\
12,800 \\
-9,000 \\
4,175\end{array}$ & $\begin{array}{r}181,000 \\
-52,000 \\
128,000 \\
-90,000 \\
41,750\end{array}$ & $203,231,491$ & $8.48 \times 10^{8}$ & $8.48 \times 10^{9}$ \\
\hline $\begin{array}{c}\text { D } \\
\text { Total }\end{array}$ & Tail 5 & 202,000 & $2,020,000$ & $1,859,850$ & $\begin{array}{l}3.76 \times 10^{8} \\
5.89 \times 10^{9}\end{array}$ & $\begin{array}{l}3.76 \times 10^{9} \\
5.89 \times 10^{10}\end{array}$ \\
\hline
\end{tabular}


the tails is destined for landfills of the underground mine, jointly with the overburdens. In this situation it is possible that, depending on the physical conditions and mixture quality, the overburden with a negative ABA will further neutralize the acidity tailing causes. Such considerations would suggest a more optimistic estimate of the acid drainage potential at site $\mathrm{B}$ (Table 6).

At site C, only ores were sampled, since there were no overburden piles. In this case, the AMD potential depends on the quantities and composition of the ores to be processed, as well as on the sulfide recovery rate during the process. The proportion of each ore type in the blend depends on the gold price, which is rather variable. Nevertheless, a gold price of US $\$ 325.00$ per oz can be assumed. In this case, the blend composition would be $72 \%$ of ore B2 $(227,054,880 \mathrm{t})$ and $24 \%$ of ore B1 $(88,299,120 \mathrm{t})$ to be exploited and processed from 1998 to 2014 . Hence, the potential for acid drainage generation would be as shown in Table 7 .
Considering a minimum recovery rate of $58 \%$ for sulfides at the "flotation" process, the acid drainage potential at the tailing dam would be only $42 \%$ of the estimate in Table 7 . The difference corresponds to the material to be settled in pools, where environmental control measures are strict. The AMD estimate for site $\mathrm{C}$ was $211 \times 10^{6}$ to $4.53 \times 10^{9} \mathrm{~m}^{3}$ of acid water at $\mathrm{pH} 2.0$ or 2.11 to $45.3 \times 10^{9} \mathrm{~m}^{3}$ at $\mathrm{pH} 3.0$ (Table 7). These values are lower than the ones established by Pinto and Nepomuceno (1998). The reason for this difference is probably the surface sampling done at the "mining front". Under such conditions, the B2 samples could be partially oxidized and might not represent the sulfide body as deeper probe sampling would.

At site D, an old tail dam (tail 5) is a potential acid drainage generator (Table 3), estimated similarly by both criteria at 376 to $399 \times 10^{9} \mathrm{~m}^{3}$ of acid water at pH 2.0 (Table 4 and 5). It is known that the dam is lined with clayey soil and environmental control is probably increasing. Nevertheless, the AMD

Table 6. Acid water generation potential of company $B$ samples

\begin{tabular}{|c|c|c|c|c|c|}
\hline \multirow{2}{*}{ Sample } & \multicolumn{2}{|c|}{ Acid water volume $\left(\mathrm{L} \mathrm{t}^{-1}\right)$} & \multirow{2}{*}{ Mass of material (t) } & \multicolumn{2}{|c|}{ Acid water volume $(1.000 \mathrm{~L}$} \\
\hline & pH2 & pH 3 & & pH2 & PH3 \\
\hline \multicolumn{6}{|l|}{ TSC criteria } \\
\hline Actual tail & 73,100 & 731,000 & 750,000 & $5.48 \times 10^{7}$ & $5.48 \times 10^{8}$ \\
\hline Future tail & 73,100 & 731,000 & $2,395,250$ & $1.75 \times 10^{8}$ & $1.75 \times 10^{9}$ \\
\hline Total & & & $3,145,250$ & $2.30 \times 10^{8}$ & $2.30 \times 10^{9}$ \\
\hline Dammed tail & 73,100 & 731,000 & $2,201,675$ & $1.61 \times 10^{8}$ & $1.61 \times 10^{9}$ \\
\hline \multicolumn{6}{|l|}{$\mathrm{H}_{2} \mathrm{O}_{2}$ criteria } \\
\hline Actual tail & 58,700 & 587,000 & 750,000 & $4.40 \times 10^{7}$ & $4.40 \times 10^{8}$ \\
\hline Future tail & 58,700 & 587,000 & $2,395,250$ & $1.41 \times 10^{8}$ & $1.41 \times 10^{9}$ \\
\hline Total & & & & $1.85 \times 10^{8}$ & $1.85 \times 10^{9}$ \\
\hline Dammed tail & 58,700 & 587,000 & $2,201,675$ & $1.29 \times 10^{8}$ & $1.29 \times 10^{9}$ \\
\hline
\end{tabular}

Table 7. Acid water generation potential of company $\mathrm{C}$ samples

\begin{tabular}{|c|c|c|c|c|c|}
\hline \multirow{2}{*}{ Sample } & \multicolumn{2}{|c|}{ Acid water volume ( $\left.\mathrm{L} \mathrm{t}^{-1}\right)$} & \multirow{2}{*}{ Mass of materials (t) } & \multicolumn{2}{|c|}{ Acid water volume $(1.000 \mathrm{~L})$} \\
\hline & pH2 & pH3 & & pH2 & РH3 \\
\hline \multicolumn{6}{|l|}{ TSC criteria } \\
\hline B1 & $-1,750$ & $-17,500$ & $88,299,120$ & $-1.55 \times 10^{8}$ & $-1.55 \times 10^{9}$ \\
\hline B2 & 20,650 & 206,500 & $227,054,880$ & $4.69 \times 10^{9}$ & $4.69 \times 10^{10}$ \\
\hline Mean & & & & $4.53 \times 10^{9}$ & $4.53 \times 10^{10}$ \\
\hline \multicolumn{6}{|c|}{$\mathrm{H}_{2} \mathrm{O}_{2}$ criteria } \\
\hline B1 & $-8,350$ & $-83,500$ & $88,299,120$ & $-7.37 \times 10^{8}$ & $-7.37 \times 10^{9}$ \\
\hline $\mathrm{B} 2$ & 4,175 & 41,750 & $227,054,880$ & $9.48 \times 10^{8}$ & $9.48 \times 10^{9}$ \\
\hline Mean & & & & $2.11 \times 10^{8}$ & $2.11 \times 10^{9}$ \\
\hline
\end{tabular}


Table 8. Acid drainage evaluation potential and costs for neutralization based on total sulfide content (TSC) of samples and the $\mathrm{H}_{2} \mathrm{O}_{2}$ digestion criteria

\begin{tabular}{|c|c|c|c|c|}
\hline \multirow{2}{*}{ Company } & \multicolumn{2}{|c|}{ Acid water volume $\left(x \mathbf{1 0}^{9} \mathrm{~m}^{3}\right)$} & \multirow{2}{*}{ Limestone amount $\left(x \mathbf{1 0}^{6} \mathrm{t}\right)$} & \multirow{2}{*}{ Neutralization cost (US\$) } \\
\hline & pH2 & pH3 & & \\
\hline \multicolumn{5}{|l|}{ TSC criteria } \\
\hline $\mathrm{A}$ & 5.28 & 52.80 & 2.64 & $13,200,000.00$ \\
\hline $\mathrm{B}$ & 0.16 & 1.61 & 0.08 & $400,000.00$ \\
\hline $\mathrm{C}$ & 4.53 & 45.30 & 2.27 & $11,350,000.00$ \\
\hline $\mathrm{D}$ & 0.40 & 4.00 & 0.20 & $1,000,000.00$ \\
\hline Total & 10.37 & 103.71 & 5.19 & $25,950,000.00$ \\
\hline \multicolumn{5}{|l|}{$\mathrm{H}_{2} \mathrm{O}_{2}$ criteria } \\
\hline $\mathrm{A}$ & 2.42 & 24.20 & 1.210 & $6,050,000.00$ \\
\hline $\mathrm{B}$ & 0.13 & 1.29 & 0.065 & $325,000.00$ \\
\hline $\mathrm{C}$ & 0.21 & 2.11 & 0.105 & $525,000.00$ \\
\hline $\mathrm{D}$ & 0.38 & 3.76 & 0.188 & $940,000.00$ \\
\hline Total & 3.14 & 31.36 & 1.568 & $7,840,000.00$ \\
\hline
\end{tabular}

potential in site $\mathrm{D}$ is probably underestimated since there were other tailing pools not sampled in our study. These pools contain around 1,191,105 $t$ of potentially acid generating tailing, as informed by the Minas Gerais Environmental Agency (FEAM).

The AMD generation potential for Minas Gerais State is presented in table 8 , but it should be kept in mind the limitations and constraints discussed above for each mine. The costs for neutralization with lime, which is the cheapest and most abundantly available neutralizing product, were estimated at US\$ $5.00 \mathrm{t}^{-1}$. Considering this cost, AMD represents a potential cost of US $\$ 7.8$ to 25.9 millions to neutralize acidity.

\section{CONCLUSIONS}

1. The estimates of the AMD generation potential differ according to the adopted criteria. They are higher when calculated based on the total content of sulfides after "aqua régia" digestion than with the acidity potential (AP) measured after peroxide oxidation. The AP calculated from the total sulfide content is probably overestimated due the presence of other sulfides such as arsenopyrite, calcopyrite, sphalerite, and pentlandite, whose stoichiometry of acid generation differs from that of pyrite. On the other hand, the peroxide analysis probably underestimated AP due to incomplete sulfide oxidation.

2. The results identified four mining sites with potential to generate acid drainage in Minas Gerais.
Jointly, these activities represent a potential to generate around 3.14 to 10.37 billions of $\mathrm{m}^{3}$ of water at $\mathrm{pH} 2$ or 31.4 to 103.7 billions of $\mathrm{m}^{3}$ of water at $\mathrm{pH}$ 3. This, in turn, represents costs of US $\$ 7.8$ and 25.9 millions for acidity neutralization with limestone. These quantities are probably underestimated because some mines were not included in the survey, and for other mines, surface samples may not represent the whole picture. A more reliable evaluation of the acid drainage potential at state level would require further studies. These studies must include a larger number of samples from mining operations not considered in this study. They should further consider the kinetics of the acid generation by simulated weathering methods.

\section{ACKNOWLEDGEMENTS}

The authors would like to thank FAPEMIG (Minas Gerais Research Foundation Agency) for the financial support of this research, as well as FEAM and the staff of the companies involved in this study. A. Daniel thankfully acknowledges the scholarship granted by CAPES (Brazilian Federal Sponsor).

\section{LITERATURE CITED}

ASPIRAS, R.B.; KEENEY, D.R \& CHESTERS, G. Determination of reduced inorganic sulfur forms as sulfide by zinc-hydrochloric acid distillation. Anal. Letters, 5:425432. 1972. 
BRANDT W. Projeto de aproveitamento de minério B2. Estudo de impacto ambiental, RPM. Paracatu, 1996. 172p.

CARUCCIO F.T. Estimating the acid potential of coal mine refuse. In: CHADWICK, M.J. \& GOODMAN, G.T., eds. The ecology of resource degradation and renewal. London, Blacwell Sci. Publ., 1975. p.35-76.

CARUCCIO, F.T \& GEIDEL, G. Acid mine drainage, the laboratory \& field settings. Knoxville, American Society for Surface Mining and Reclamation, 1996. 58p.

CORRÊA, M.L.T.; MELLO, J.W.V.; RIBEIRO, A.C. \& COSTA, L.M. Métodos de análise de sulfetos em amostras de rochas e sedimentos. R. Bras. Ci. Solo, 26:103-115, 2002.

EMPRESA BRASILEIRA DE PESQUISA AGROPECUARIA EMBRAPA. Serviço Nacional de Levantamento e Conservação de Solos. Manual de métodos de análises de solo. Rio de Janeiro,. 1979. Não paginado.

GEIDEL, G. \& CARUCCIO, F.T. Geochemical factors affecting coal mine drainage quality. In: BARNHISEL, R.I.; DARMODY, R.G. \& DANIELS, W.L., eds. Reclamation of Drastically Disturbed Lands. Madison, America Society of Agronomy, 2000. p.105-130. (Agronomy Monograph, 41)

GRUBE Jr., W.E.; JENCKS, E.M.; SINGH, R.M.; SMITH, R.M. \& WILSON, H.A. Mine spoil potentials for water quality and controlled erosion. USEPA/OWR proj. 14010 E.J.E. Morgantown, West Virginia University, 1971. 128p.

KERR, P.F. Optical mineralogy. 4.ed. New York, McGraw Hill, 492p. 1977.

MELLO, J.W.V. \& ABRAHÃO, W.A.P. Geoquímica da drenagem ácida. In: DIAS, L.E. \& MELLO, J.W.V., eds. Recuperação de áreas degradadas. Viçosa, Folha de Viçosa, 1998. p.45-58.

MURTHY, A.R.V. \& SHARADA, K. Determination of sulphides sulphur in minerals. Analyst, 85:299-300, 1960.

NECKERS, J.W. \& WALKER, C.R. Field test for active sulfides in soil. Soil Sci., 74:467-470, 1952

O'SHAY, T.; HOSSNER, L.R. \& DIXON, J.B. A modified hydrogen peroxide oxidation method for determination of potential acidity in pyritic overburden. J. Environ. Qual., 19:778-782, 1990.

PETERSEN, L. Chemical determination of pyrite in soils. Acta Agric. Scand., 19:40-44, 1969.

PINTO, A.C.P. \& NEPOMUCENO, A.L. Testes de predição e controle do processo de drenagem ácida na Rio Paracatu Mineração S.A. In: DIAS, L.E. \& MELLO, J.W.V., eds. Recuperação de áreas degradadas. Viçosa, Folha de Viçosa, 1998. p. 59-68.
PONS, L.J. A quantitative microscopical method of pyrite determination of soils. In: FONERIUS, A., ed. Soil micromorphology. New York, Elsiever Publ., 1964. p.401-409.

RICHARDS, I.G.; PALMER, J.P. \& BARRATT, P.A. Water quality. In: The reclamation of former coal mines and steelworks. Amsterdam, 1993. 718p. (Studies in Environmental Science, 56)

SANTANA FILHO, S. Impactos do processo de drenagem ácida sobre recursos hídricos no estado de Minas Gerais. Viçosa, MG, Universidade Federal de Viçosa, 2000. 173p. (Tese ge Mestrado)

SINGER, P.E. \& STUMM, W. Acid mine drainage: The ratedetermining step. Science, 167:1121-1123, 1970.

SKOUSEN J.G.; SEXSTONE, A. \& ZIEMKIEWICZ, P.F. Acid mine drainage control and treatment. In: BARNHISEL, R.I.; DARMODY, R.G. \& DANIELS, WL, eds. Reclamation of Drastically Disturbed Lands. America Society of Agronomy, 2000. p.131-168. (Agronomy Monograph, 41)

SMITTENBERG, J.; HARMSEN, G.W.; QUISPEL, A. \& KEENEY, D.R. Rapid methods for determination different types of sulphur compounds in soil. Plant Soil, 3:353-360, 1951.

SOARES E.R. Mobilidade de metais pesados em materiais provenientes do complexo carboenergético de CandiotaRS. Viçosa, MG, Universidade Federal de Viçosa, 1995. 95p. (Tese de Mestrado)

SOARES, E.R.; MELLO, J.W.V.; COSTA, L.M. \& CORREAA, M.L. Drenagem ácida em materiais provenientes da mineração de carvão de Candiota, RS. Geonomos, 5:6772, 1997.

SOBEK, A.A.; SCHULLER, W.A.; FREEMAN, J.R. \& SMITH, R.M. Field and laboratory methods applicable to overburdens and minesoils. Washington, DC, 1978. EPA60012-78-034.

SORENSON, D.L.; KNEIB, W.A. \& PORCELHA, D.B. Determination of sulfide in pyritic soils and minerals with a sulfide ion electrode. Anal. Chem., 51:1870-1872, 1979.

WINCHELL, A.N. Elements of optical Mineralogy. 3.ed. Description of minerals. New York, John Wiley \& Sons, 1933. 459p. Part 3.

YONEDA, S. Studies on polder soils in Japan. XVI. Rapid method for determining oxidizable sulfur and change of soil reaction of sea muds and polder soils. Soil Sci. Rep., 17:39-46, 1961

ZIEMKIEWICS, P.F.; SKOUSEN, J.G.; BRANT, D.L.; STENER, P.L. \& LOVETT, R.J. Acid mine drainage treatments with armored limestone in open limestone channels. J. Environ. Qual., 26:718-726, 1997. 